\title{
Kebijakan Redaksional MQTV dalam Penyiaran Berita
}

\author{
Adib Darissalam \\ UIN Sunan Gunung Djati Bandung \\ adibdaris@gmail.com
}

\begin{abstract}
The religious life is experiencing rapid development in conjunction with the revolutionary changes in the media. At the stage of modernization, entered the twentieth century, the development of the media is an industry with a wide range of cultures that make it up. But when the religious interests collide with culture media system, there was friction that easily trigger sensitivity. Harmonization of religion and culture media, which never happened in the centuries to write the media triumph, now it is often disturbed and provoked by the dynamics posed by culture media. In the context of the relationship between religion and culture of this media, one major question that deserves to be answered in this paper is; how to bridge the interests of religion (as something divine, sacred and ceremonial) with the media culture as an industrial capitalist. What implications arise and which will result from this relationship. Will a positive effect on the religious or otherwise.
\end{abstract}

Keywords: Television, Editor Policy, MQTV

\begin{abstract}
ABSTRAK
Televisi menjadi bagian yang tak terpisahkan dari kehidupan manusia. Program berita saat ini seolah menjadi program andalan di berbagai stasiun televisi. Tidak heran jika isu yang sama disajikan dalam sudut pandang yang berbeda. Hal tersebut tidak terlepas dari kerangka berfikir yang sengaja dibentuk oleh pihak redaksi dalam menentukan kebijakan penyiaran. Hasil penelitian menunjukkan bahwa dalam pemilihan berita MQTV selalu memilih berita yang tidak bertolak belakang dengan visi misi dan ideologi perusahaan, yaitu ideologi Islam. Dalam penyiaran dan program acara yang disajikan MQTV termasuk pemberitaan selalu mengedepankan aspek-aspek yang berkenaan dengan dakwah Islam. MQTV memiliki misi membangun insan televisi yang memiliki integritas tinggi terhadap dunia Islam. Dalam hal ini berusaha menjadi inspirasi serta pemicu pada hal-hal bersifat positif terhadap pemirsanya, mencerdaskan kehidupan masyarakat dengan landasan nilai-nilai Islam.
\end{abstract}

Kata Kunci : Televisi, Kebijakan Redaksi, MQTV 


\section{Pendahuluan}

Perkembangan dunia pertelevisian semakin pesat. Begitu juga yang terjadi di Bandung dimana tingkat penetrasi televisi tergolong sangat tinggi bahkan dapat melebihi kota-kota besar lainnya di Indonesia khususnya di Jawa Barat. Dengan hadirnya penyiaran baru mengenai televisi lokal, setiap daerah dapat menghadirkan tayangan khas lokal untuk warganya.

Hal tersebut berawal dari kemunculan reformasi 1998 yang telah melahirkan euforia desentralisasi. Selain melahirkan perangkat perundang-undang yang mengatur desentralisasi politik berupa otonomi daerah juga melahirkan perundang-undangan yang meregulasi desentralisasi penyiaran. Alasannya memang tepat, untuk menumbuhkan nuansa keberagaman yang selama orde baru terberangus. Karena itulah muncul Undang-Undang Penyiaran (UUP) 2002 yang mengamanatkan realisasi Sistem Stasiun Berjaringan (SSB).

Tujuan UU Penyiaran 2002 No. 32 yang mengatur tentang SSB nyata adalah untuk meletakkan pondasi bagi sistem desentralisasi penyiaran. Agar daerah dapat menikmati manfaat yang lebih baik dari ranah penyiaran, baik di wilayah isi siaran (diversity of content) maupun di wilayah bisnis ekonomi penyiaran (diversity of ownership). Maknanya dari UU ini adalah untuk memberikan keleluasaan pembangunan ekonomi, kesejahteraan masyarakat di daerah agar penyiaran tidak terkonsentrasi dipusat.

Namun sayang, peraturan tidak mulus karena kalangan televisi swasta, pemilik modal besar mengaku belum mampu. Hingga muncul pasal 60 yang mengatur tentang batas akhir waktu bagi lembaga penyiaran televisi untuk bersiaran dengan SSB. Stasiun televisi nasional diberikan limit lima tahun untuk menyiapkan infrastruktur atau SDM agar bisa melaksanakan undang-undang penyiaran ini. Informasi dari mmw.rumabdunia.net bahwa efek dari UUP 2002 membuat televisi lokal menggeliat. Di Bandung telah muncul 11 televisi lokal diantaranya Bandung Tv, Pajajaran, IM TV, Setiabudi TV, City Chanel, MQ Tv dan Ganseha TV.

Banyaknya televisi yang hadir di tengah-tengah masyarakat baik televisi pemerintah dan swasta mempunyai ideologi masingmasing. Dengan ideologi tersebut mereka dapat menjelaskan bagaimana informasi yang disajikan dapat dibuktikan kebenarannya. Bukti-bukti pendukung seperti gambar, kutipan langsung narasumber, grafis dan lain sebagainya baik secara langsung ataupun tidak membuat pemirsa percaya terhadap informasi yang disiarkan televisi tersebut. 
Tidak heran jika isu yang sama disajikan dalam sudut pandang yang berbeda. Di sini tidak terlepas dari kerangka berpikir yang sengaja dibentuk oleh perusahaan pers yang memiliki kemampuan untuk mempengaruhi masyarakat dan membentuk opini publik. Kerangka berpikir tersebut menjadi sarana untuk mempengaruhi bagaimana suatu isu dipahami oleh masyarakat. Sebagai contoh program paket berita, setiap stasiun televisi mempunyai cara yang berbeda-beda dalam menyiarkan program tersebut kepada pemirsanya.

Kehadiran paket berita telah menjadikan pemirsa kembali mempunyai kepercayaan bahwa yang namanya jurnalisme televisi bisa menarik minat dan bahkan mampu bersaing dengan tayangan hiburan, (Wardhana, 1997:147). Sepeti tanyangan paket berita Agenda Kita yang disiarkan oleh MQTV 60UHF. MQTV sebuah TV lokal swasta yang khusus untuk pemirsa Bandung. MQTV dengan tayangan hiburan, edukasi, dakwah dan informasi lokal. Program Agenda Kita lebih memusatkan pada program berita yang dikemas dalam bentuk news magazines, yang mengakomodir berbagai acara yang diselenggarakan masyarakat umum, seperti yayasan, lembaga pendidikan maupun organisasi lainnya, termasuk instansi pemerintah dan perusahan yang berpotensi dapat diajak untuk kerja sama.

Acara ini hadir setiap hari minggu pada jam 19.00-19.30 petang. Isi acara tersebut terbagi menjadi 4 segment, segment 1 dan 2 menampilkan liputan berbagai kegiatan masyarakat selama satu minggu kebelakang. Segmen 3 menampilkan slot "Layak Diagendakan" yaitu liputan tentang tempat wisata, atau kuliner, atau tempat lain yang direkomendasikan redaksi untuk dijadikan agenda baru oleh penonton. Segmen 4 menampilkan beberapa slot, yaitu slot "Agenda Anda", grafis yang menginformasikan berbagai kegiatan yang akan diselenggarakan 1 minggu kedepan, slot "Bisnis Sahabat", grafis yang menginformasikan bisnis masyarakat, seperti info jual beli tanah, rumah, barang dsb, slot yaitu grafis yang menginformasikan lowongan kerja bagi masyarakat, serta slot "Tips Dari Sahabat", yaitu tips dalam menyusun acara, jadwal atau agenda kerja. Setiap episode menampilkan 6 berita, dengan durasi 1 berita 4 menit.

\section{Kebijakan Redaksional}

Menurut Den Oleh dalam wmw.oleb07.wordpress.com kebijakan redaksional (Editorial Policy), adalah ketentuan yang disepakati oleh redaksi media massa tentang kriteria berita atau tulisan yang boleh dan tidak boleh 
dimuat atau disiarkan, juga kata, istilah, atau ungkapan yang tidak boleh dan boleh dipublikasikan, sesuai dengan visi dan misi media. Dalam media radio/TV, kebijakan redaksi soal penggunaan bahasa dituangkan dalam standar kata siaran. Kebijakan redaksional ditetapkan sebagai standar bagi wartawan dan penyiar demi ciri khas media sekaligus menjaga keseragaman bahasa di kalangan wartawan/penyiar.

Kebijakan redaksional lebih memusatkan perhatian kepada bagaimana aspek-aspek dan misi ideal yang dijabarkan dalam peliputan dan penempatan berita, laporan, tulisan dan gambar yang sesuai dengan kepentingan dan selera khalayak yang relatif beragam. Karena sifat khalayak anonim dan heterogen, maka bahasa jurnalistik yang dipilih tentu harus memenuhi asas anonim dan heterogenitas itu. Agar memudahkan seluruh pengelola, maka pedoman pemakaian bahasa jurnalistik ini lazimnya dihilangkan dalam sebuah buku khusus intern sebagai rujukan resmi dalam peliputan, penulisan, pemuatan, penyiaran, atau penayangan berita, laporan, tulisan dan gambar pada media bersangkutan, (www.richafebrina.blogspot.com).

Media massa menjadi Defining Agency bagi konsepsi yang kita miliki tentang realtas sosial. Ippman (dalam Deddy, 1986:61) menyatakan bahwa : "realitas sosial sebagian merupakan media made reality. Respon yang digalang pun terkadang bukan secara langsung ditujukan kepada suatu objek peristiwa yang digambarkan picture in our head.

Media massa pada dasarnya menciptakan benak pemirsa dari hasil dari hasil arahan yang direncanakan oleh pengelola media massa. Ada dua macam menyangkut kbijakan dalam media massa. Pertama, kepentingan untuk menerima atau menyesuaikan diri dengan sesuatu realitas sosial tertentu. Kedua, kepentingan untuk menciptakan (mengubah) suatu realitas sosial tertentu lainnya. Tarik menarik akan nampak dalam dua macam kepentingan tersebut, kondisi yang ideal dalam kebijakan pengelolaan media massa harus bisa menegakkan kepentingan diantara keduanya.

Sedangkan "Produk jurnalisme (berita), tidak dapat dipisahkan dari kebijakan redaksional yang ada dalam newsroom, termasuk penghayatan nilai-nilai jurnalisme yang dianut oleh redaktur dan jurnalis di lapangan. Kebijakan redaksi adalah pedoman (baik tertulis maupun tidak tertulis), yang menjadi buku suci redaksi dalam mengelola news room (mulai dari menentukan isu liputan, angle liputan, memilih narasumber, penugasan, sampai format tulisan, dan sebagainya). Dengan kata lain, kebijakan redaksi (editorial policy) merupakan kaidah bagi setiap langkah operasional pemberitaan." 
Pernyataan tersebut dikutip dari J Anto seseorang yang bekerja di kajian Informasi, Pendidikan dan Penerbitan Sumatera (KIPPAS) yang ditulis di internet, (buntomijanto.wordpress.com).

Menurut Werner J. Severin dan James W.T dalam Teori Komunikasi (2005: 261), Media mengacu pada kemampuan media, dengan liputan berita yang diulang-ulang, untuk mengangkat pentingnya sebuah isu dalam benak publik. Sedangkan menurut Steiner dan Miner (1997:22), kebijakan mengarahkan tindakan untuk mencapai sasaran atau tujuan dengan menentukkan petunjuk yang harus diikuti. Kebijakan ini dirancang untuk menjamin konsistensi tujuan dan untuk menghindari keputusan yang berwawasan sempit dan berdasarkan kebijakan.

Kebijakan umumnya dianggap sebagai pedoman untuk bertindak atau saluran untuk berfikir. Secara lebih khusus kebijakan adalah pedoman untuk melaksanakan suatu tindakan. Kebijakan mencakup seluruh bidang (universe) tempat tindakan akan dilakukan. Bidang ini dapat menjadi luas, misalnya jika kebijakan berkenaan dengan suatu pernyataan umum keinginan manajemen. Kebijakan mungkin dianggap sebagai kode yang menunjukkan arah yang harus ditenpuh. Kebijakan biasanya berlangsung lama. Nyatanya kebijakan cenderung berlaku terlalu lama tanpa peninjauan dan penyempurnaan sampai batas tertentu.

Dari apa yang telah dikemukakan, jelaslah bahwa kebijakan cukup penting dalam teori peran. Kebijakan adalah alat untuk mencapai tujuan, karena itu menerangkan apa yang seharusnya dilakukan sebagai lawan dari apa yang sedang dilakukan. Kebijakan kalau dilaksanakan memungkinkan peramalan peran secara pasti. (Steiner dan Miner, 1997:22).

Menurut Kurt Lang dan Gladys Engel Lang (1959) dalam Werner J. Severin dan James W.T dalam Teori Komunikasi (2005: 264) menyatakan, Media massa memaksakan perhatian pada isu-isu tertentu. Media massa membangun citra publik tentang figur-figur politik. Media massa secara konstan menghadirkan objek-objek yang menunjukkan apa yang hendaknya dipertimbangkan, diketahui, dan dirasakan individuindividu dalam masyarakat.

Sebagaimana dikatakan Paul Appleby dalam Steiner dan Miner, (1997:22) bahwa kebijakan diklasifikasikan menurut ruang lingkup dan urutan pentingnya. Kita dapat berbicara kebijakan induk (master policy) atau kebijakan utama yang mencakup area yang sama. Kedua konsep tersebut adalah sama. Kebijakan ini dapat diperbandingkan dengan kebijakan progran yang didefinisikan di atas, namun lebih baik terdapat dalam suatu perusahaan dan mencakup lebih banyak kegiatan. 
Kedua, kebijakan dapat diklasifikasikan menurut tingkat organisasinya. Segala sesuatu yang diputuskan pada tingkat manajemen adalah kebijakan. Segala sesuatu yang berada dalam suatu perusahaan dan mencakup lebih banyak kegiatan. Ketiga, kebijakan menurut subjek material/ subjek non material. Keempat, kebijakan sesuai dengan tujuan dan fungsinya. Dan kelima, kebijakan pribadi manajer. Seorang redaktur telah menggariskan kepercayaan (credo), filisofi dan standar perilaku yang merupakan kebijakan-kebijakannya.

Metode penelitian yang digunakan peneliti adalah kualitatif dengan analisis deskriptif. Informasi kualitatif digunakan agar gambaran tentang fenomena sosial yang disajikan dalam penelitian menjadi semakin jelas dan hidup serta nuansa-nuansa fenomena sosial dapat ditampilakan. Sedangakan penelitian deskriptif memaparkan situasi atau peristiwa, tidak mencari atau menjelaskan hubungan, tidak menguji hipotesis atau membuat prediksi (Rakhmat, 1993:24).

\section{Hasil Dan Pembahasan}

MQTV merupakan salah satu televisi lokal yang berada di Bandung dengan siaran bernuansa Islam. Motto MQTV ialah "Sahabat Penyejuk Hati". Saat ini, MQTV sudah resmi siaran menjadi TV lokal Bandung pada 60 UHF yang coverage areanya mencakup wilayah kota Bandung dan sebagian kota-kota sekitarnya. Fokus utamanya adalah memberikan tontonan berkualitas kepada masyarakat melalui pengkajian acara yang sesuai dengan kebutuhan dan kapasitas pemirsa. Salah satunya dengan program acara paket beritanya yaitu Agenda Kita. Sebagai televisi lokal, MQTV berisi dan menyajikan peristiwa-peristiwa lokal yang terjadi disana.

Penanggung jawab utama suatu berita adalah pemimpin redaksi. Yang bertanggung jawab sebagai pemimpin redaksi di MQTV yaitu manajer departemen program dan produksi. Ia sebagai penanggung jawab utama seluruh pemberitaan yang ditayangkan dalam job description atau pembagian tugas di jajaran redaksi. Pemimpin redaksi memiliki tanggung jawab yang besar karena dialah yang memegang kebijakan atau policy pemberitaan.

Policy pemberitaan merupakan ketentuan baku yang tidak bisa ditawar. Hal ini karena policy pemberitaan ditentukan berdasarkan visi dan misi dari stasiun penyiaran MQTV Bandung. Dalam menentukan policy pemberitaan kepentingan pemerintah dan kepentingan publik diutamakan. Dari berbagai berita yang masuk ke redaksi, pemilihan sebuah berita merupakan sebuah proses jurnalistik yang 
urgensinya cukup berpengaruh bagi media massa. Berbagai pertimbangan menyangkut isi pemberitaan diperhitungkan secara matang dan teliti, tentunya agar menghasilkan berita yang benar-benar layak dikonsumsi oleh masyarakat sesuai dengan visi dan misi media massa tersebut.

Berangkat dari visi dan misi tersebut redaktur dapat dengan mudah mendeteksi dan mempertimbangkan mana peristiwa yang layak mana yang tidak. Berdasarkan proximity (kedekatan) MQTV memprioritaskan pemberitaan lokal. Pemberitaan tersebut berkenaan dengan sosial budaya, pendidikan dan politik yang terjadi di wilayah Bandung. Karena MQTV mempunyai perspektif bahwa pemberitaan yang disampaikan harus mendidik dan mempengaruhi masyarakat.

Bidang redaksi MQTV yang dimotori oleh Iman Budiman selaku pemimpin redaksi, merumuskan garis besar penilaian kelayakan berita. Kebijakan redaksional yang dibuat pemred dalam memilih berita diambil berdasarkan visi dan misi media serta bobot news value yang dikandungnya. MQTV memiliki konsep pemberitaan yaitu jurnalisme damai. Berita dinilai layak tayang apabila berdasarkan dari kriteria yang sesuai dengan konsep yang menjadi acuan bagi para wartawan dan reporter.

Pemimpin redaksi memberikan arahan secara garis besar untuk menyusun dan menentukan berita, kemudian diserahkan secara penuh kepada produser program yaitu Azan Mukzaman. Adapun dalam pelaksanaan teknisnya bisa dilakukan berbagai cara, baik itu dengan cara formal maupun informal. Pengambilan kebijakan secara formal (rapat redaksi) dilaksanakan bila ada peristiwa yang dinilai besar. Sementara pengambilan kebijakan secara informal lebih sering dilakukan. Biasanya crew agenda kita melakukannya pada hari senin pagi yang dihadiri oleh manajer departemen program dan produksi selaku pemred, produser program, reporter dan kameramen.

Berdasarkan kedekatan dengan pemirsa MQTV menjadikan MQTV lebih memprioritaskan berita-berita lokal, dibandingkan dengan peristiwa lain yang tidak ada sangkut-pautnya dengan pemirsa di wilayah Bandung. Terkecuali bila ada berita nasional yang diadakan atau terjadi di Bandung.

Sampai saat ini $99 \%$ prioritas berita yang ditayangkan MQTV merupakan berita-berita lokal di wilayah Bandung. Hal ini guna menjaga dan mempertahankan ciri khas MQTV sebagai stasiun televisi lokal. Pemred menambahkan, Muatan lokal kita akan terus dipertahankan, 
kalaupun nantinya ada perkembangan, untuk sementara ini sembilan puluh sembilan persen berita MQTV merupakan berita lokal. Ciri khasnya sopan dan santun dalam setiap ucapan kalimat dan tidak fulgar.

Jenis pemberitaan MQTV soft news karena dalam program berita yang diusung MQTV dalam bentuk news magazine. Dalam setiap episode memutarkan kurang lebih hanya 2 berita utama dan selanjutnya diisi dengan berita prakiraan cuaca, jadwal shalat, jadwal penerbangan pesawat (iklan), jadwal keberangkatan kereta (iklan), dan no telepon penting kota bandung.

Peran pemimpin redaksi (disini manajer departemen program dan produksi) memiliki tanggung jawab yang sangat besar dalam bidak redaksi. Tugas utamanya untuk mengendalikan kegiatan keredaksian di media televisi yang meliputi penyajiaan berita, penentuan topik liputan, pencarian fokus pemberitaan, serta pemilihan berita utama. Dalam melaksanakan tugasnya ia dibantu oleh beberapa orang tenaga yang disebut produser program acara dan editor.

Bagi bidang redaksi MQTV, pemimpin redaksi dibantu produser program untuk menentukan berita utama. Dirinya yang bertugas serta memiliki kewenangan dalam memilih dan menentukan berita untuk ditayangkan. Seperti dijelaskan Iman Budiman bahwa tanggung jawab untuk menentukan berita telah diserahkan kepada produser program acara, akan tetapi bila ada kendala akan dikonsultasikan dalam rapat bersama dengan jajaran redaksi dan pemimpin redaksi.

MQTV selalu berupaya menyesuaikan pola siarannya yang lebih berorientasi kepada keinginan dan kebutuhan khalayak. Dalam menyusun pola acara beritanya MQTV mengklasifikasikan isi beritanya ke dalam segi sosial budaya, pendidikan dan politik. Sedangkan dalam segi kriminal MQTV tidak memberitakannya.

Melihat segmentasi acara yang dibuat oleh redaksi MQTV, berita masuk dalam segmen 1 dan dua. Berita yang disuguhkan dalam setiap edisi Agenda Kita hanya memunculkan satu atau dua berita dari 7 segmen yang ditayangkan. Peneliti melihat bahwa Agenda Kita termasuk minim berita. Hal ini disebabkan karena minimnya reporter dan wartawan untuk program berita tersebut. Reporter dan wartawan diambil dari para peserta PKL dari instansi pendidikan yang dimotori oleh produser program acara.

Berbeda dengan media televisi lain yang memunculkan banyak berita dan diselang oleh iklan. Sedangkan MQTV sendiri dalam pemberitaannya tanpa diselingi iklan atau layanan komersil lainnya. Ini menjadikan tayangan berita yang disuguhkan terkesan memakan waktu 
lebih lama dan dilanjutkan dengan informasi yang mengiringi segmen berita. Alasannya, agar berita sampai kepada pemirsa itu dibutuhkan penjelasan yang akurat dan perlu adanya penekanan dalam setiap pemberitaan. MQTV sendiri menggunakan berita sebagai media dakwah dan tidak menjadikan berita berita sebagai komersialitas. Disini membantu masyarakat agar tetap focus terhadap pemberitaan tersebut. Pesan yang disampaikan dalam berita agar sampai kepada pemirsa tanpa menimbulkan pertanyaan karena tidak memahami aka nisi berita tersebut.

Berita yang diunggulkan MQTV pada edisi bulan Mei-April yaitu mengenai pendidikan. Karena menurut presentase mencapai 38,5\% dalam bulan tersebut. Menurut manejemen, materi pendidikan selalu menjadi sorotan utama, sesuai dengan penjabaran misi MQTV yaitu mencerdaskan masyarakat. Sedangkan materi berita hiburan dan budaya menempati posisi kedua. Hiburan dan budaya selalu menjadi perbincangan orang ramai. Maka dari itu hiburan dan budaya menjadi salah satu topik yang akan selalu menghiasi layar kaca.

Sedangkan berdasarkan kategori berita, semua berita yang disajikan MQTV pada program agenda kita menggunakan berita ringan (soft news). Yaitu berita yang menunjuk pada peristiwa yang lebih bertumpu pada unsur-unsur keterkaitan manusiawi, seperti pesta pernikahan bintang film, atau seminar, loka karya dan lain- lain. Hal tersebut dikarenakan program agenda kita dikemas dalam bentuk news magazines, yang mengakomodir berbagai acara yang diselenggarakan masyarakat umum, seperti yayasan, lembaga pendidikan maupun organisasi lainnya, termasuk instansi pemerintah dan perusahan.

Dilihat dari lokasi peristiwanya, ada berita yang terjadi di tempat tertutup (indoor news), ada pula berita yang terjadi di tempat terbuka (outdoor news). Berita tentang seminar, pengadilan, lokakarya, berlangsung di tempat terutup. Berita jenis ini masuknya kategori berita ringan (soft news). Disebut berita ringan karena berita tersebut tidak sampai mengguncangkan perhatian serta tidak menimbulkan dampak yang luas terhadap masyarakat.

Berita tentang bencana alam, terjadi di tempat terbuka. Berita jenis ini umumnya masuk kategori berita berat (hard news). Tentu saja tidak setiap berita yang terjadi di tempat terbuka termasuk hard news. Banyak berita yang terjadi di tempat terbuka masuk kategori soft news. Singkatnya hard news dan soft news hanya menunjuk pada kualitas berita dan bukan pada lokasi peristiwa. 
Secara umum proses produksi pemberitaan agenda kita dimulai dari tahap rapat perencanaan oleh manajer, produser dan koordinator lapangan. Proses selanjutnya yakni pencarian berita oleh reporter di lapangan. Berita kemudian diketik dan diserahkan ke produser untuk disunting/diedit. Setelah proses penyuntingan selesai, berita kemudian masuk ke bagian produksi untuk kemudian di layout.

Sedangkan proses pembuatan naskah beritanya tidak banyak berbeda dengan proses yang berlangsung di stasiun televisi lain. Secara lebih rinci proses pembuatan naskah berita diantaranya: 1) Manajer departemen program dan produksi mengadakan rapat seluruh produser, asisten produser dan koordinator juru kamera, untuk membahas rencana dan masalah institusional yang berkaitan dengan liputan/ redaksi/ perusahaan. 2) Selain rapat yang dipimpin oleh manajer departemen program dan produksi, ada juga rapat harian yang dilakukan oleh produser yang bertujuan untuk mengkoordinasikan rencana dan gagasan liputan, mencari solusi atas masalah yang muncul, menjaga kesinambungan materi liputan dan mengevaluasi tayangan dan hasil liputan. 3) Hasil rapat redaksi dituangkan dalam notulen. Rapat juga membuat lembar penugasan yang menjadi acuan Koordinator Peliputan. 4) Reporter dan juru kamera mengimplementasikan penugasan, dengan melakukan liputan di lapangan. Tim lapangan tersebut juga wajib mengembangkan dan memperkaya informasi. 5) Dalam perjalanan kembali ke studio, reporter dan juru kamera dapat mendiskusikan hasil liputan dengan produser. 6) Setelah berita di dapat dari wartawan, produser mempunyai waktu satu minggu untuk menyaring, menyeleksi dan mereview gambar yang layak tayang atau tidak, setelah itu dikonsultasikan kepada manajer. 7) Setelah dikonsutasikan dan layak tayang kemudian produser menugaskan reporter untuk membuat naskah berita. 8) Setelah naskah dibuat kemudian pengisian voice over. 9) Kemudian masuk ke ruang editor dan di edit menjadi berita yang lengkap.

MQTV Bandung untuk lebih mencerdaskan masyarakat dilaksanakan dengan memuat informasi lokal yang mengarah pada segi pemberitaan mendidik. Di samping itu dengan menginformasikan kejadian seluas-luasnya mengenai apa yang terjadi di wilayah lokal. Paling tidak setelah masyarakat menyaksikan tayangan MQTV Bandung, minimalnya menimbulkan sebuah inspirasi serta memicu pada hal- hal bersifat positif. Bahasa yang digunakan dalam 
menyiarkan berita yaitu memakai bahasa yang sudah baku. Yang khas bagi MQTV yaitu pada awal pemberitaan diawali dengan mengucapkan "assalamu'alaikum". Hal ini tidak terlepas dari ideologi MQTV sendiri yang menjunjung tinggi nilai-nilai dakwah Islam.

Salah satunya dapat tercermin dari nilai-nilai perusahaan MQTV Bandung bidang program dan berita benar, amanah, sederhana, inovatif, solutif. Sementara persepsi yang hendak dibangun MQTV Bandung tidak sebatas informasi semata, namun lebih pada edukasi dan dakwah dengan landasan-landasan Islam yang disebut dakwahtainment.

Program acara yang disajikan dapat disaksikan oleh berbagai kalangan. Segmentasi pemirsa MQTV dari kalagan bawah, menengah dan atas. Oleh karena itu, pemberitaan disajikan yaitu pemberitaan dalam segi sosial budaya,pendidikan, politik. Sedangkan segi kriminal tidak masuk dalam redaksi pemberitaan MQTV.

Untuk menarik minat pemirsa, MQTV tidak seperti televisi lain yang menggunakan lembaga survei untuk menentukan rating sebuah program acara. Karena menurut produser hal tersebut terkadang kurang valid. Untuk mengatasi hal tersebut, MQTV menyediakan program acara yang bernama "Ust. Jaga," yang berisi konsultasi pemirsa MQTV mengenai hal-hal seputar Islam via telepon. Dari data pemirsa yang dikumpulkan melalui acara tersebut, kemudian dikunjungi dan diwawancara. Dari hasil wawancara, direksi MQTV akan mengetahui apa yang dibutuhkan oleh pemirsa MQTV, begitu juga untuk program Agenda Kita.

Bidang redaksi umumnya tidak menemui kendala proses penyusunan dan penentuan berita, semua masih bisa teratasi dengan lancar. Terkadang kendala hanya sebatas perlengkapan teknis peralatan saja, namun itu berada di luar tanggung jawab bidang redaksi sebagai penyedia peralatan. Begitu pula dengan masalah pasca pemberitaan yang berhubungan dengan kasus, MQTV tidak pernah terjerat kasus pelanggaran pers (delik pers) yang besar. Persoalan delik pers yang menyangkut berita masih bisa diselesaikan lewat jalan musyawarah di kantor redaksi. Karena pada umumnya masyarakat yang mengadu hanya perorangan (personil) saja dan tidak bersangkutan dengan intansi atau sebuah lembaga

Produser berpandangan, bahwa sampai saat ini masyarakat Bandung khususnya para pemirsa MQTV cukup cerdas untuk bisa menilai mana media yang baik dan tidak. Masyarakat kini lebih peka dan aktif untuk menanggapi segala informasi terhadap isi pemberitaan di MQTV, baik itu melalui telepon maupun komentar melalu web kami. 
Sebuah perusahaan penerbitan pers merupakan kesatuan dari berbagai sistem kerja yang paling berperan satu dengan yang lain. Institusi perusahaan pers di MQTV, mencakup pada bidang redaksi dan bidang usaha. Masing- masing bidang mempunyai tanggung jawab, peran dan tujuan yang sama, yakni untuk menjalankan roda perusahaannya. Untuk itu diperlukan sistem kerja yang paling pengertian dan kesadaran penuh terhadap tanggung jawab masing- masing.

Pada dasarnya, kegiatan pers bukan semata-mata merupakan alat menyampaikan informasi semata, melainkan pada perkembangannya menjadikan institusi pers sebagai lembaga bisnis dengan menjual informasi maupun iklan. Maka tidak heran jika kebijakan yang diambil media berorientasi pada bisnis media. Redaksi selalu melakukan koordinasi dengan bagian bidang usaha untuk melihat mana isu yang bagus dan strategis untuk dijadikan materi pada berita agenda kita. Sehingga penilaian kelayakan dan penentuan berita juga nantinya akan berimbas bagi peningkatan program acar pada media televisi pada umumnya. Pemimpin redaksi akan mengambil kebijakan yang beriringan dengan kepentingan komersial media. Dirinya memadukan antara fungsi penyangan media sebagai penjual informasi dengan fungsi bisnis industri pers.

Namun, MQTV beranggapan walaupun hal tersebut sudah tidak asing lagi dalam dunia media, komersialitas sepatutnya tidak mengesampingkan ideologi dan visi misi media. Setiap televisi harus berpegang teguh dengan idealismenya dan harus memahami visi dan misi perusahaan karena akan menentukan jati diri stasiun televisi tersebut. Segi komersial tidak boleh menagalahkan ideologi televisi. Stasiun televisi harus bersifat independen tidak boleh tercampur dengan golongan dan partai. Bila dimasuki oleh segi komersial yang berlebihan maka stasiun televisi akan mengikuti apa yang dikehendaki oleh uang. Kalau hal tersebut terjadi, ideologi stasiun televisi akan terkikis sedikit demi sedikit.

Ideologi yang dibangun oleh MQTV sangat kuat sehingga segala bentuk komersialitas tidak dapat menghilangkan visi misi dan ideologi yang sudah terbentuk dari awal beridirinya perusahaan tersebut. Dikarenakan MQTV merupakan media televisi dakwah yang mengisi program-program acaranya dengan nuansa Islam, begitu pula dengan kebijakan yang akan ditentukan dalam setiap programnya termasuk pada Agenda Kita.

Bidang usaha merupakan partner dalam menentukkan penetapan sebuah berita. Bentuk kerjasamanya berupa laporan yang 
diperoleh dari pengembangan masyarakat di lapangan. Bidang usaha menangkap berbagai gejolak serta kehausan masyarakat terhadap informasi yang sedang hangat.

Bidang redaksi memiliki tuntutan lebih peka menangkap agenda yang akan dihadapi publik dan menjadikannya sebagai agenda kebijakan. Dimana agenda media merupakan agenda publik dan agenda publik menjadi sebuah agenda kebijakan. Apa yang dianggap penting oleh masyarakat, maka dianggap penting pula oleh media, demikian sebaliknya. Saling berpengaruh antara dua unsur tersebut mempengaruhi kebijakan dalam menilai berita yang menjadi materi dalam pemberitaan agenda kita.

MQTV merupakan salah satu televisi lokal yang lahir dan beredar di wilayah Bandung, dilihat dari segi pemberitaan tidak lepas untuk menyajikan peristiwa- peristiwa lokal yang terjadi di sana. Berdasarkan isu- isu pemberitaan yang diangkat serta wilayah sirkulasi terbitnya, 99 $\%$ merupakan peristiwa lokal di Wilayah Bandung berikut kota- kota kecil yang berada disekitarnya seperti Cimahi dan Sumedang.

Jelas terlihat MQTV merupakan sebuah televisi lokal, baik itu dilihat dari segi muatan beritanya, wilayah siarnya serta segmentase sendiri merupakan lokal. Seperti dijelaskan di atas, dari segi bahasa yang digunakan bisa jadi bahasa nasional karena segmentase MQTV yang begitu heterogen. Tidak hanya pada masyarakat Bandung yang berbahasa Sunda saja, melainkan seluruh lapisan masyarakat. Kebijakan redaksional pun disesuaikan dengan visi misi media secara konteks kelokalan.

Kebijakan bidang redaksi merupakan sebuah operasional dari visi misi yang dianut oleh sebuah penyiaran pers, dimana keberadaannya sangat menentukan arah pemberitaan. Dengan perangkat tersebut pihak redaksi menerjemahkan fungsi umum pers, baik sebagai media informasi, hiburan, pendidikan serta kontrol sosial. Kebijakan redaksional menentukan langkah televisi dari proses awal sampai akhir acara televisi itu ditayangkan. Begitu pula dengan pengambilan kebijakan yang menyangkut berita utama.

Begitu pula pemimpin redaksi MQTV mempunyai penilaian tersendiri bahwa berita yang layak ditayangkan, yakni merupakan sebuah berita yang terbaik dari berita- berita baik. Prosesnya melalui beberapa pemilihan dan pemilahan, maka akan ditinjau tingkat kemenonjolan berita tersebut. Perumusan tentang penilaian kelayakan berita yang akan ditayangkan berangkat dari visi dan misi MQTV serta nilai berita (news value) yang terkandungnya. Acuannya bisa 
dipergunakan oleh wartawan yang meliput maupun produser dalam memilih berita.

Nilai berita (news value) dapat terdeteksi dari 11 kriteria kelayakan, yakni Pertama, keluarbiasaan (unusualness) adalah sesuatu peristiwa yang luar biasa (news is unusual). Kedua, kebaruan (newness) adalah semua yang terbaru. Ketiga, akibat (impact) adalah segala sesuatu yang berdampak bagi masyarakat luas. Keempat, aktual (timeiness) adalah berita yang baru saja terjadi atau sedang terjadi. Kelima, kedekatan (proximity) yang mengandung dua arti, kedekatan geografis dan psikologis. Keenam, informasi (information) adalah informasi yang memberi banyak nilai manfaat pada masyarakat. Ketujuh, konflik (conflict) adalah segala unsur atau syarat dengan dimensi pertentangan. Kedelapan, orang penting (publikfigure news maker) adalah tentang orang penting, ternama dan figure publik. Kesembilan, kejutan (surprising) adalah sesuatu yang datangnya tiba- tiba atau di luar dugaan. Kesepuluh, ketertarikan manusiawa (buman interest) yakni lebih menimbulkan getaran pada suasana hati, suasana kejiwaan dan alam perasaan. Kebelas, seks $(\operatorname{sex})$.

Terdapat kesamaan yang mendasar dari news value yang dikelompokkan oleh Haris Sumadiria dan news value perspektif MQTV. Meski sifatnya hanya cukup memuat tiga dari 11 kriteria lain, namun hal ini telah memberikan landasan penting dalam proses penentuan sebuah berita di MQTV. Tetapi bukan berarti bidang redaksi mengabaikan news value yang lainnya, tentunya kadar yang terangkum terkadang berbeda pada setiap isu yang akan diangkat.

Berangkat dari visi misi dan news value tersebut, produser dapat dengan mudah mendeteksi dan mempertimbangkan mana peristiwa yang layak ditayangkan. Pasalnya dalam menjalankan kebijakan redaksional keredaksian seperti penyeragaman gaya bahasa khususnya untuk naskah berita, MQTV belum memiliki buku panduan resmi (style book). Semua hanya berpegang pada kebijakan tidak tertulis atau menurut pemred merujuk kepada news value dan visi misi media. Produser menilai kelayakan sebuah berita yang akan ditayangkan merupakan berita yang terbaik dari berita- berita baik yang masuk ke redaksi.

Sebenarnya penulis menilai dalam sebuah media elektronik seperti televisi,buku panduan (style book) dianggap perlu sebagai acuan resmi yang dapat dipegang oleh para wartawan maupun redaktur. Fungsinya sebagai acuan tertulis yang dapat selalu dibawa kemana saja dalam menjalankan operasional redaksi, sehingga tidak melenceng 
dari visi misi media. Jadi, kebijakan redaksional terumuskan bentuknya dalam sebuah buku pegangan bidang redaksi, bukan hanya sebatas pegangan yang tidak tertulis. Buku ini merupakan penjabaran dari berbagai konseptual kebijakan redaksi yang bertujuan untuk lebih mewujudkan idealisme MQTV agar tidak keluar dari ketetapan yang digariskan.

Agar bisa menjaga dan mempertahankan ciri khasnya sebagai televisi lokal maka yang harus menjadi prioritas utama MQTV yakni peristiwa di wilayah Bandung. Dari segi pengambilannya, bidang redaksi bertumpu pada motto bidang program dan berita MQTV sendiri yakni Benar, Amanah, Sederhana, Inovatif dan Solutif.

MQTV mengusung konsep "Jurnlisme Damai" dalam pemberitaan Agenda Kita. Seperti yang dijelaskan Iman Budiman (pemred), bahwa konsep pemberitaan yang diusung MQTV lebih cenderung ke Jurnalisme Damai. Karena berita-berita yang diangkat itu tidak mengambil yang sifatnya kriminal, perampokan, perzinahan, pemerkosaan, atau berita-berita yang mengandung unsur-unsur kekerasan, kerusuhan ataupun demo-demo, MQTV sama sekali tidak mengambil berita yang seperti itu. Jurnalisme damai dalam upaya menyampaikan fokus beritanya lebih pada efek kekerasan yang tidak tampak, seperti kerusakan sosial, kerusakan budaya moral, hancurnya masa depan, maupun trauma pihak yang menjadi korban, bukan produk fisik dari konflik dan kekerasan semata, seperti potongan mayat, rumah ibadah yang hangus, wanita dan anak terlantar. Hal ini bertujuan untuk menarik empati audience, bahwa konflik yang disertai kekerasan hanya mendatangkan kerugian.

Salah satu pegangan dalam menjalankan oprasional teknis kerja bidang redaksi dijelaskan oleh Azan Mukzaman (Produser) dalam wawancara bersama penulis 17 Juli 2011. bahwa secara umum rekonstruksi berita lazimnya dibuat dengan pola piramida terbalik, karena dianggap mudah untuk dipahami. Pola piramida terbalik juga umumnya lebih dipahami wartawan MQTV dalam penulisan naskah berita dan secara teknis memudahkan redaktur untuk mengedit beritanya. Dengan menggunakan bahasa komunikatif yang patuh pada kaidah bahasa Jurnalistik dan merujuk pada EYD (Ejaan Yang Disempurnakan). Sedangkan bahasa Jurnalistik yakni bahasa yang digunakan para wartawan, redaktur atau pengelola media massa. Tentunya dalam menyusun dan menyajikan laporan peristiwa (berita) secara benar, aktual,penting serta menarik dengan tujuan mudah dipahami isinya dan cepat ditangkap maknanya. 
Sementara kewajiban penggunaan EYD bagi pers sebagaimana terumus dalam pedoman yang dikeluarkan oleh Persatuan Wartawan Indonesia (PWI) pada 10

November 1976 di Jakarta. Dari 10 pedoman, salah satunya menyebutkan "Wartawan hendaknya secara konsekuen melaksanakan pedoman Ejaan Bahasa Indonesia yang disempurnakan. Hal ini juga harus diperhatikan oleh para korektor karena kesalahan yang paling menonjol dalam surat kabar sekarang ini ialah kesalahan ejaan.”

Penggunaan pola penyusunan secara piramida terbalik berarti pesan berita disusun secara deduktif. Kesimpulan dinyatakan terlebih dahulu pada paragraf pertama baru kemudian disusul dengan penjelasan dan uraian yang lebih rinci pada paragraf- paragraf berikutnya. Paragraf pertamamerupakan rangkuman fakta terpenting dari seluruh uraian kisah berita (news story). Dengan demikian rumusannya semakin ke bawah, paragraf tersebut semakin tidak penting. Disajikan

dengan piramida terbalik karena berpijak pada tiga asumsi, yakni: memudahkan pembaca, memudahkan editor memotong bagian berita dan memudahkan Jurnalis menyusun berita.

Sedangkan proses pembuatan naskah beritanya tidak banyak berbeda dengan proses yang berlangsung di stasiun televisi lain. Secara lebih rinci proses berawal dari data berikut gambar berita yang diperoleh reporter di lapangan, kemudian diserahkan kepada produser. Produser mempunyi waktu selama satu minggu untuk memilah dan memilih berita yang layak tayang atau tidak. Setelah berita terpilih, produser menugaskan wartawan untuk membuat naskah sesuai dengan fakta yang ada. Kemudian berita yang sudah di buat di edit dengan di isi oleh VO (Voice Over) dan di tayangkan.

MQTV selalu menggunakan VO dalam setiap penayangan beritanya. Dari awal tayangan voice over sudah masuk hingga akhir pemberitaan. Dalam pemberitaan tanpa menggunakan anchor atau penyaji berita. Sedangkan voice over ialah video atau gambar pendek (biasanya sekitar satu menit) yang diiringi dengan kata-kata penyiar. VO biasanya digunakan untuk menceritakan sebuah topik dalam waktu yang singkat. Jika stasiun televisi telah menerima gambar video dari suatu peristiwa, maka cara tercepat untuk menyampaikan gambar dan berita itu adalah dengan menggunakan format voice over.

Perbedaan ini sangat jelas sekali, setelah peniliti melihat tayangan pemberitaan Agenda Kita, peneliti dapat membaca bahwa konsep pemberitaan MQTV layaknya majalah berita. Tanpa 
penyaji berita hanya suara voice over yang memandu dan tayangan berita. Menurut produser, Agenda Kita selain pemberitaan yang berbentuk news magazine, dalam pemberitaannya juga memfokuskan tayangan dan isi berita kepada pemirsa. Sedangkan menurut pemred, pemberitaan MQTV seperti tayangan feature, pemberitaanya panjang dan menggunakan voice over tanpa menggunakan anchor.

Sebuah perusahaan penerbitan pers merupakan kesatuan dari berbagai sistem kerja yang paling berperan satu dengan yang lain. Institusi perusahaan pers di MQTV, mencakup pada bidang redaksi dan bidang usaha. Masing- masing bidang mempunyai tanggung jawab, peran dan tujuan yang sama, yakni untuk menjalankan roda perusahaannya. Untuk itu diperlukan sistem kerja yang paling pengertian dan kesadaran penuh terhadap tanggung jawab masing- masing.

Kegiatan pers bukan semata-mata merupakan alat menyampaikan informasi semata, melainkan pada perkembangannya menjadikan institusi pers sebagai lembaga bisnis dengan menjual informasi maupun iklan. Maka tidak heran jika kebijakan yang diambil MQTV Bandung berorientasi pada bisnis media. Hal tersebut sesuai dengan butir misi MQTV yaitu "Menggali potensi komersial dengan melibatkan masyarakat, khususnya dalam mengembangkan usaha kecil dan menengah yang mandiri". Akan tetapi bagi MQTV walaupun hal tersebut sudah tidak asing lagi dalam dunia media, komersialitas sepatutnya tidak mengesampingkan ideologi dan visi misi media. Komersialitas yang di bangun MQTV sesuai dengan ideologi dan tidak keluar dari jalur tersebut.

Setiap televisi harus berpegang teguh dengan idealismenya dan harus memahami visi dan misi perusahaan karena akan menentukan jati diri stasiun televisi tersebut. Segi komersial tidak boleh menagalahkan idealogi televisi. Stasiun televisi harus bersifat independen tidak boleh tercampur dengan golongan dan partai. Kalau sudah dimasuki oleh segi komersial yang berlebihan maka stasiun televisi akan mengikuti apa yang dikehendaki oleh uang. Kalau hal tersebut terjadi, ideologi stasiun televisi akan terkikis sedikit demi sedikit.

Dari berbagai pemaparan yang dijelaskan di atas, untuk menyederhanakan proses kebijakan redaksi dalam menentukan sebuah berita terjadi seperti berikut. Proses pertama setelah semua berita terkumpul dari reporter yang bertugas di lapangan kemudian diserahkan pada produser program. Produser program merumus pada proyeksi yang telah dilakukan, ia menguji nilai kelayakan serta bobot yang terkandung dalam berita. Kriteria penilaiannya, setiap berita yang 
akan ditayangkan harusmemiliki news value, berlandaskan terhadap visi misi media. Otoritas pemred akan dilakukan jika terjadi kebuntuan produser dalam menentukan berita.

Tekanan dan porsi berita lokal akan mempunyai efek yang lebih besar. Penerimaan audiens terhadap media merupakan salah satu faktor yang bisa meningkatkan kredibilitas MQTV dikalangan audiens yaitu masyarakat Bandung. Berkaitan dengan masalah ini, diasumsikan bahwa bila media mampu mengangkat kredibilitas maka efek yang ditimbulkan masyrakat akan meningkat.

Sebuah peristiwa besar yang terjadi di wilayah Bandung tentu sepenuhnya berpotensi akan menjadi topik berita. Kepekaan bidang redaksi dituntut untuk dapat mendeteksi agenda yang dihadapi publiknya. Kepentingan media mempengaruhi kebijakan dalam menilai kelayakan berita.

Peneliti telah menguraikan di atas bahwa salah satu misi terpenting yang diemban pers khususnya MQTV yakni mencerdaskan masyarakat. Tentunya dalam hal ini membangkitkan jati diri masyarakat Bandung (lokal) sehingga lebih maju. Untuk memaksimalkan peran pers tersebut perlu perubahan dalam pola pikir dan mentalitas media dan publik yang terlibat didalamnya.

Bidang redaksi umumnya tidak menemui kendala proses penyusunan dan penentuan berita, semua masih bisa teratasi dengan lancar. Terkadang kendala hanya sebatas perlengkapan teknis peralatan saja, namun itu berada di luar tanggung jawab bidang redaksi sebagai penyedia peralatan. Begitu pula dengan masalah pasca pemberitaan yang berhubungan dengan kasus, MQTV tidak pernah terjerat kasus pelanggaran pers (delik pers) yang besar. Persoalan delik pers yang menyangkut berita masih bisa diselesaikan lewat jalan musyawarah di kantor redaksi. Karena pada umumnya masyarakat yang mengadu hanya perorangan (personil) saja dan tidak bersangkutan dengan intansi atau sebuah lembaga.

\section{Penutup}

Berdasarkan hasil penelitian tentang kebijakan redaksional MQTV Bandung dalam penyiaran Agenda Kita, ada beberapa hal yang dapat ditarik kesimpulan ditinjau dari pemilihan berita Agenda Kita, bidang redaksi MQTV selalu memilih berita yang tidak bertolak belakang dengan visi misi dan ideologi perusahaan. Sedangkan ideologi yang dimiliki MQTV yaitu ideologi Islam. Dalam penyiaran dan program 
acara yang disajikan MQTV termasuk pemberitaan selalu mengedepankan aspek-aspek yang berkenaan dengan dakwah Islam. Berdasarkan kehendak MQTV dalam penyiaran Agenda Kita terhadap pemirsanya, MQTV merumuskannya pada misi MQTV pada poin kedua yaitu membangun Insan televisi yang memiliki integritas tinggi terhadap dunia Islam. Berdasarkan dukungan kebijakan terhadap berita Agenda Kita meliputi beberapa faktor, yaitu faktor orientasi bisnis media, relevansi dan bernilai guna bagi masyarakat, keberadaan media lain.

\section{Daftar Pustaka}

Alo Liliweri. (1991). Memahami Peran Komunikasi Massa Dalam Masyarakat. Bandung: PT. Citra Aditya Bakti

Asep Saeful Muhtadi (1999). Jurnalistik Pendekatan Teori dan Praktik. Jakarta: Logos

Asep Syamsul M. Romli. (2005). Jurnalistik Terapan Pedoman Kewartawanan dan Kepenulisan. Cetakan Ketiga. Bandung: Batic Press

AS. Haris Sumadiria. (2008). Jurnalistik Indonesia Menulis Berita dan Feature.Cetakan Ketiga . Bandung: Simbiosa Rekatama Media (2006). Bahasa Jurnalistik Panduan Praktis Penulis dan Jurnalis. Bandung: Simbiosa Rekatama Media

Askurifai Baksin (2009). Jurnalistik Televisi Teori dan Praktik. Bandung: Simbiosa Rekatama Media

Aubrey B. Fisher. (1978). Teori - teori Komunikasi. Bandung : CV Remadja Karya

Dedy Iskandar Muda. (2008). Jurnalistik Televisi Menjadi Reporter Profesional. Bandung: PT. Remaja Rosdakarya

Dedy Mulyana (2004). Komunikasi Populer, Kajian Komunikasi dan Budaya Kontemporer. Bandung: Pustaka Bani Quraisy.

Dedy N. Hidayat. (1986). Aplikasi Penelitian Komunikasi dalam Menunjang Kebijakan Isi Surat Kabar. Jakarta: Sinar Harapan

Elvinaro Ardianto-Lukiati Komala Erdinaya (2005). Komunikasi Massa Suatu Pengantar. Cetakan Kedua. Bandung : Simbiosa Rekatama Media

Elvinaro Ardianto-Lukiati Komala Erdinaya-Siti Karlinah (2007). Komunikasi Massa Edisi Revisi. Bandung : Simbiosa Rekatama Media 
Hikmat Kusumaningrat-Purnama Kusumaningrat (2009). Jurnalistik teori dan praktik. Bandung: Rosda Karya

Jalaluddin Rakhmat. (1993). Metode Penelitian Komunikasi. Cetakan Ketiga. Bandung: Remaja Rosda Karya

Kustadi Suhandang. (2007). Manajeman Pers Dakwah. Bandung: Penerbit Marja dan Kode Etik.. Bandung: Nuansa Cendikia.

Morissan. (2004). Jurnalistik Mutakhir. Bogor: Galia Indonesia

Onong Uchjana Effendy. (1986). Dimensi- dimensi Komunikasi. Bandung: Alumni.

Veven Sp. Wardhana. (1997). Kapitalisme Televisi dan Strategi Budaya Massa. Yogyakarta: Pustaka Pelajar

Werner J. Severin-James W. Tankard, JR. (2009). Teori Komunikasi Sejarah, Metode, dan Terapan di Dalam Media Massa. Cetakan Keempat. Jakarta: Kencana Prenada Media Group 